\title{
Features of Criminal Behavior of Persons with Mental Disorders, which Were Found to Be Limited Sane
}

\section{Особливості кримінальної поведінки осіб із психічними розладами, які були визнані обмежено осудними}

\author{
Nataliia Zaviazkina \\ Dr. in Psychology, Assistant Professor, Taras Shevchenko Na- \\ tional University of Kyiv, Kyiv (Ukraine) \\ ORCID ID: https://orcid.org/0000-0001-5565-8959 \\ E-mail:nmuz@ukr.net
}

\section{Наталія Завязкіна}

Доктор психологічних наук, доцент, Київський національний університет імені Тараса Шевченка, м. Київ (Україна)

\section{ABSTRACT}

The paper notes the urgency of the problem of criminal responsibility of persons with mental disorders, which does not exclude sanity. This is due, on the one hand, to an increase in mental health conditions among the perpetrators due to the general decline in the level of mental health of the population and, on the other hand, to the lack of a clear legislative solution to the criminal and legal significance of mental anomalies in the individualization of punishment. The need to analyze the impact on the implementation of the wrongful act of the relevant data set was noted.

The aim of the article is to disclose the specifics of the criminal conduct of persons with mental disorders, which were found to be limited sane.

Address for correspondence, e-mail: kpnu_lab_ps@ukr.net Copyright: (C) Zaviazkina Nataliia

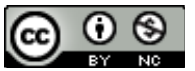

The article is licensed under CC BY-NC 4.0 International (https://creativecommons.org/licenses/by-nc/4.0/)

(c) Zaviazkina Nataliia

DOI (article): https://doi.org/10.32626/2227-6246.2020-49.37-59 
The following methods were used to achieve the tasks: theoretical analysis of scientific literature, psychodiagnostic and statistic methods.

In the study 103 cases of persons undergoing a comprehensive psychological and psychiatric examination were analyzed and found to be unable to fully understand the nature and significance of their actions during the offence and were found to be limited sane.

The results of the research. The study shows that a person's mental state is determined by the forensic psychiatric examination, or complex forensicpsychiatric examination, appointed after the fact of committing a socially dangerous act by that person, if there is evidence of doubt about his sanity. It has been found that mental disorders and certain states of the psyche, affecting the intellectual and volition sphere of the individual's activities, do not always automatically deprive it of the opportunity at the time of the crime to realize the actual nature and public danger of their actions (inaction) or to direct them.

Conclusions. It has been proved that the person who committed a socially dangerous act requires the study of violations in the intellectual and emotionalvolitional spheres, criticality, self-control, as well as the study of the criminal situation, which allows to assess the degree of actualization and influence of the psychological disorder available in the sub-expert, his ability to regulate fully his behavior during the period of committing illegal actions.

Key words: criminal behavior, limited sanity, individualization of punishment, mental disorders, intellectual activity, strong-willed processes, emotional sphere.

\section{Introduction}

In recent years, experts have noted the growth of number of persons with various mental disorders in society. The scientific studies have revealed a tendency to deteriorate the mental health of the population of Ukraine (Гриневич \& Линский, 2005; Марута \& Мінько, 2003) due to an increase in non-psychotic disorders. Unfortunately, modern living conditions of Ukrainian society cause an increase in the number of stress factors, which in turn create emotional tension of people, as well as contribute to the emergence of mental disorders of different degrees of expression.

This data is also reflected in the study of criminal behavior and confirmed by researchers in forensic psychology and (C) Zaviazkina Nataliia

DOI (article): https://doi.org/10.32626/2227-6246.2020-49.37-59 
psychiatry. Thus, some researchers in this field emphasize the increase of exactly non-psychotic disorders; in their opinion it is an unconditional clinical fact (Ілейко \& Первомайський, 2003; Первомайский, 1992). At the same time, it should be noted that among the criminals recognized as imputed but suffering from such mental disorders, persons with reduced adaptive properties, changes in internal control mechanisms of the person, narrowing of the choice of adequate situation of solutions and options of behavior, facilitation of the mechanism of carrying out impulsive acts come to the fore (Первомайский, 1992; Зайцев, 2003; Назаренко, 2002).

The relevance of the problem of criminal liability of persons with mental disorders, not excluding sanity, is caused, on the one hand, by the increase among the persons who committed a crime, persons with mental disabilities due to the general decline in the level of mental health of the population, and, on the other hand, lack of the accurate legislative solution of a question about criminal value of mental anomalies at punishment individualization (Vinkers et al., 2011; De Rosa et al., 2013).

The inclusion of a new precept of law to the Criminal code of Ukraine corresponds to a concept of limited sanity became a precondition essential to the domestic legislation. This norm provides protection of the rights of persons which mental disorder is limited to boundary forms of pathology and does not exclude sanity, however definitely affects their illegal behavior.

The purpose of the article consists in disclosure of features of data on criminal behavior of persons with mental disorders which were recognized restrictedly as responsible.

\section{The tasks of the article}

1. To carry out the theoretical and methodological analysis of criminal behavior of persons with mental disorders which were recognized as restrictedly responsible.

(C) Zaviazkina Nataliia

DOI (article): https://doi.org/10.32626/2227-6246.2020-49.37-59 
DOI: https://doi.org/10.32626/2227-6246.2020-49 2020. випуск 49

2 . To reveal psychological features of formation of criminal behavior at persons with mental disorders which were recognized as restrictedly responsible.

3. To study the characteristics of criminal behavior at persons with mental disorders, which were appointed to complex judicial psychology-psychiatric examination.

4. To prove the expediency of studying of criminal behavior at persons with mental disorders, which were recognized as restrictedly responsible.

\section{Methods and techniques of research}

The study used a theoretical analysis of the scientific literature, which helped to clarify the approaches of modern scientists to understand the formation of criminal behaviour in persons with mental disorders. By means of psycho-diagnostic and statistical methods the conclusions of complex judicial psychology-psychiatric examinations were analyzed. The provided data allowed us to formulate conclusions of rather conducted research and to define the prospects of further scientific research.

\section{Results and their discussion}

During recent years the researchers used the term «methodology of forensic-psychiatric examination» quite often. So, B. V. Shostakovych, making a start from the general theory of knowledge, includes the general and legislatively fixed ideas and norms of activity, the principles of activity and its temporary characteristics (staging) in the concept of methodology of the forensic-psychiatric diagnosis. It reduces diagnosis of a mental disorder to three stages: the collection of information about the patient, the analysis of this information, synthesis and assessment of data of information and creation of the diagnosis. Proving the methodology of the forensic-psychiatric diagnosis, the author allocates two main stages: establishment of the diagnosis of a mental disorder and its comparison to po(C) Zaviazkina Nataliia

DOI (article): https://doi.org/10.32626/2227-6246.2020-49.37-59 
sitions of psychological criterion of the corresponding precept of law. The ratio of intellectual and strong-willed components of legal (psychological) criterion which are in all precepts of law providing establishment of this or that legally significant ability is considered (Шостакович, 2005).

Existence of mental anomalies can influence considerably on formation of the personality, perception of surrounding reality, a way of life and behavior. Influence of mental disorders (anomalies) on a mental condition of the persons who made criminal actions can be a miscellaneous: for these persons thresholds of sensitivity, emotional stability, ability to realized self-checking, tendency to a self-mutilation, rancor, nonconformity etc. can be changed (Антонян \& Бородин, 1987; Лунц, 1966).

Sanity, that is recognition of the subject's ability to act, being guided by consciousness and will, has a certain psychological and legal contents. For ascertaining of sanity it is necessary to find out ability to conscious and strong-willed behaviour in those limits in which the decision about socially dangerous actions (inaction) is developed, made and implemented. When deciding the issue of decency, the level of intelligence and will, which is fully inherent in a specific behavioural act, is revealed. That is, the concept «sanity" characterizes a mental condition of the criminal during crime commission.

The insanity is established at emergence of reasonable doubts in mental full value of the person. If a degree of mental disorders was so considerable that the moment of awareness by the subject of criminality and behavior was complicated, there was a need to consider such mental anomalies as the softening circumstances (Карпец, 1984; Иванников, 2006). The insanity is determined by two criteria: medical, which is understood as the presence of mental disorders, and legal, which expresses the inability to realize the actual nature and public danger of their actions (inaction) or to manage them as a result of this disorder. The criterion of insanity formulated as inability to

(C) Zaviazkina Nataliia

DOI (article): https://doi.org/10.32626/2227-6246.2020-49.37-59 
DOI: https://doi.org/10.32626/2227-6246.2020-49 2020. випУск 49 understand value of the actions and / or to manage them, is evaluated as psychological criterion, means inability of the person to realize the actions only at the time of act commission, but does not indicate the lack of consciousness in general (Сафуанов, 1998).

According to some authors, about $65 \%$ of those who were referred for questioning due to doubts about their conviction are persons who recognize them but have severe mental disorders. However, the "value» of mental disorder, which does not exclude sanity, is directly connected with concrete socially dangerous actions. Therefore, it is extremely important to analyze the influence (if yes, that how) of anomalies of mentality, the nature and severity of which are insufficient to make a person condemned in relation to this act on the acceptance and implementation of the decision concerning a crime. At insanity the behavior is caused (in most cases) by painful frustration. The behavior and motivation of irresponsible persons with mental features are caused, first of all, by psychopathological regularities which influence the mechanisms of conscious and strongwilled behavior, but not the psychological reasons (Морозова \& Савина, 2011; Приходько, 1998; Балабанова, 1998).

Like insanity, the limited sanity is shown in total two criteria, namely clinical and legal (psychological). The medical criterion of limited sanity is defined in case of identification of one of the following types of mental disorders: chronic mental disorder, temporary mental disorder, dementia, other disease state of mentality, various psychopathies (character accentuation, disorder of inclinations and habits, etc.). The legal (psychological) criterion of limited sanity, similar to the criterion of insanity, differentiates into intellectual and strong-willed signs. This criterion reflects ability of the person to be a subject of criminal liability (Вандыш-Бубко \& Сафуанов, 2009).

At the same time the intellectual sign implies that the person at the time of commission of crime is not capable to realize the actual nature and public danger of the actions (inaction). (C) Zaviazkina Nataliia

DOI (article): https://doi.org/10.32626/2227-6246.2020-49.37-59 
The strong-willed sign is shown that the person is not capable to operate the behavior in full. For ascertaining the legal (psychological) criterion of limited sanity it is enough to define one of the specified elements (Гнетнев, 2012).

The study and systematization of complexes of changes in particular disorders of mental activity and their importance in the analysis of torts are of particular importance. That is not only accounting of "contribution" of a particular borderline disorder of mental activity to the development of a criminal situation, for example, anomalies of mental development or age-related changes of the central nervous system, but also the influence of the whole psychological complex of variables. It can be the intellectual level, performance, special attention, emotional manifestations of accentuation of character, shortterm episodes of stressful character, etc. (Морозова \& Савина, 2011).

Mentally ill people who pose a social danger have a specific set of clinical, psychological and social characteristics, the knowledge of which allows you to predict and reduce the probability of commission of heavy delicts (Хамитов, 2003).

Even the expressed forms of mental disorders do not directly determine the socially important behavior of the person, therefore the expert opinion on violation (or preservation) of one or another legally significant ability is not derived from the diagnosis of a mental disorder. A clinical psychologist has differentiation criteria for different disorders of mental activity and has the ability to integrate their pathopsychological symptoms.

I. A. Kudriavtsev allocated the following pathopsychological symptom complexes: schizophrenic, organic, oligophrenic, psychopathic and symptom complex of psychogenic disorganization, which corresponds to reactive psychoses in the clinic. All these pathopsychological symptom complexes are close to nosological specificity of psychopathological frustration and represent a stage of preliminary diagnosis of a disease 
(Кудрявцев, 1999). In the complemented classification of V. M. Bleykher and al. the allocation of functional orientation of a pathopsychological syndrome is provided, being dominating in the general structure of psychopathological frustration. According to authors, this classification of the register syndromes allows to approach the nosological specificity of mental disorders more precisely and differentially, to specify the nature and pathopsychological diagnosis of the intellectualmnestic and affective personality-based changes arising owing to various etiopathogenetic factors of a disease (Блейхер etc., 2009). The rationale for a key expert opinion requires an analysis of the relationship between the syndromic characteristics of mental disorder and personality entities that govern legally the significant personality behavior.

The justification of the key expert opinion requires the analysis of the relationship between the syndromic characteristics of mental disorders and the personality-based formations, regulating legally significant behavior of the personality. Most of all such requirements do special knowledge in pathopsychology. Answering a question on the ability of a subject to realize the actual nature and public danger of the actions (inaction) or to direct them, psychiatrists based on medical and legal (psychological) criterion of sanity / insanity rely on data obtained from a pathopsychological examination.

In our study, 103 cases of individuals who underwent comprehensive psycho-psychiatric examination and were found to be unable to fully understand the nature and significance of their actions during the offense period, were found to be only limited convictions.

Figure 1 presents the data that showed the most often recognized patients with the following diagnoses were the most commonly recognized: the patients with various disorders of organic origin $(32.4 \%)$ were on the first place, on the second patients with various forms of schizophrenia $(24.3 \%)$, on the third - mentally retarded ones $(19.2 \%)$. The subgroup of men(C) Zaviazkina Nataliia

DOI (article): https://doi.org/10.32626/2227-6246.2020-49.37-59 
DOI: https://doi.org/10.32626/2227-6246.2020-49 2020. випуск 49

tally healthy persons $(7.1 \%)$ is created mainly by persons who have been certified and have not been identified any mental disorders.

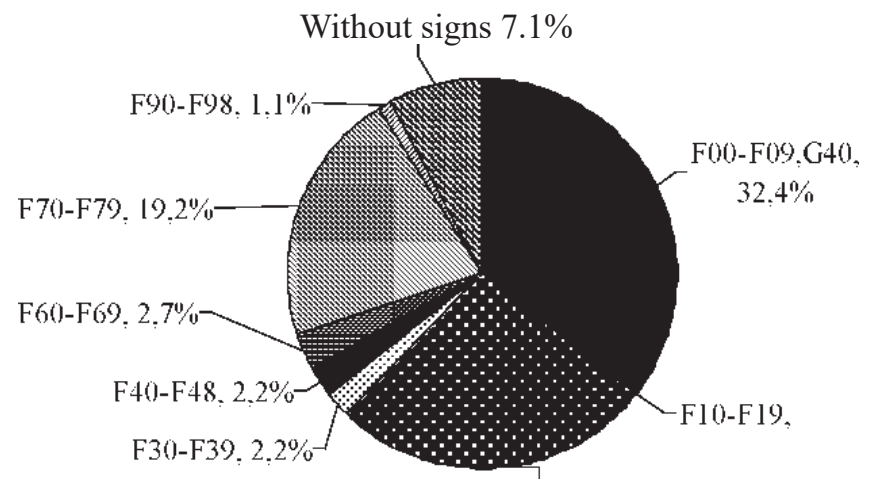

F20-F29, 24,3\%

Fig. 1. Nosological structure of examinations in criminal process

The available mental disorder leads to consciousness disorganization. In the subjectively significant situations the «accidental» stereotype of behavior dominates. Such state leads to the violation of one of the most important mechanisms of human activity - ability to choose the behavioral act.

Entering the public relations, the personality proves oneself through the combination of psychological features. Therefore, the individual properties, activity of the individual are decisive in human behavior. Crime is a kind of behavior, it has socially important character, its implementation is one of the social manifestations of personality. Even in such specific sphere as crime, the person acts as a public being. In his behavior the properties of the personality are shown in all situations (Медведєв, 2012).

In Fig. 2 we see that by prevalence of articles in the establishment of a limited conviction, the articles related to theft and robberies comprise greater percentage.

(C) Zaviazkina Nataliia

DOI (article): https://doi.org/10.32626/2227-6246.2020-49.37-59 
Art. 307, 309

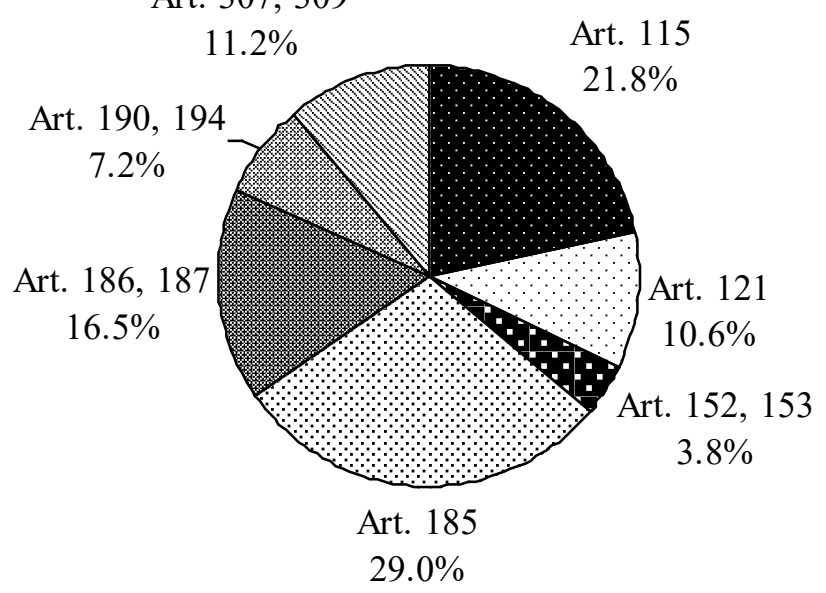

Fig. 2. Dynamics of prevalence of articles in criminal proceedings

The data obtained by us correspond to opinion of experts who note that mental disorders cause weakening of the controlling consciousness functions, limit alternative opportunities of the choice of actions in these or those situations. In the criminal situation in some sub-expert group the regulation of behavior is carried out at initially very low level that is shown in underestimation of important parameters of a situation, insufficient planning of the purposes, difficulties of the organization of the sequence of actions etc. In others, the violation of regulation at the time of delict is caused by pathogenic impact of situational factors on links of a potential system of selfcontrol (Лапшина, 2006).

According to the percentage parameters in the selection the number of men was dominated. It should be noted when studying criminal actions it is necessary to consider the factor that the sex remains one of key parameters which has not only biological characteristic, but also defines hierarchy of valuable orientations (Fig. 3).

(C) Zaviazkina Nataliia

DOI (article): https://doi.org/10.32626/2227-6246.2020-49.37-59 


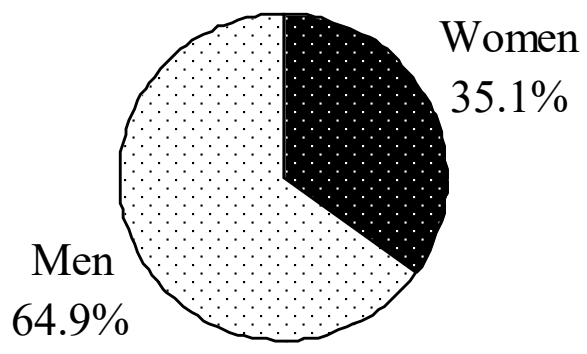

Fig. 3. The classification by sex

The age factor appears to be interesting. Most of the respondents were young, working-age (37\%), which is explained by the peculiarities of the debut of various nosological forms (Fig. 1) and also the following reasons: labor unemployment, absence of the family or poor family, surrounding environment, etc. According to some authors, the main percentage of the persons who committed one or another offense is the persons of working-age, without constant income that increases the level of psychological readiness for crime commission.

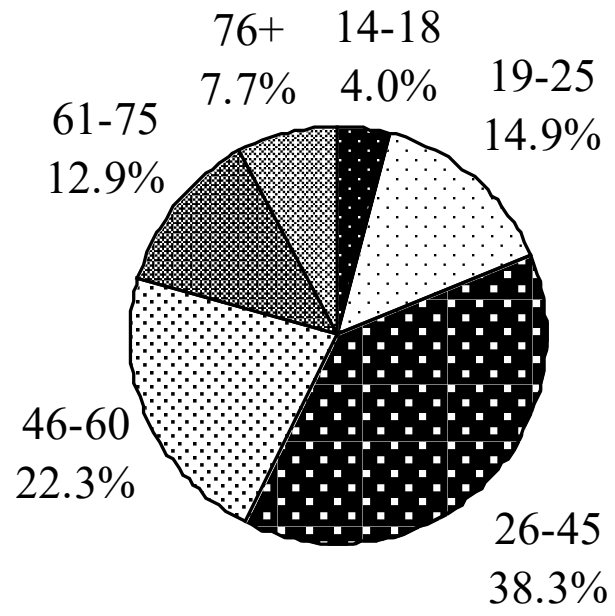

Fig. 4. The distribution by age

(C) Zaviazkina Nataliia

DOI (article): https://doi.org/10.32626/2227-6246.2020-49.37-59 
DOI: https://doi.org/10.32626/2227-6246.2020-49 2020. ВиПУСК 49

According to the analysis of our data we observe the vast majority of unemployed persons, including those with disabilities, and single people (Fig. 5-7), being defined by one of risk factors of criminal behavior at persons of young age.

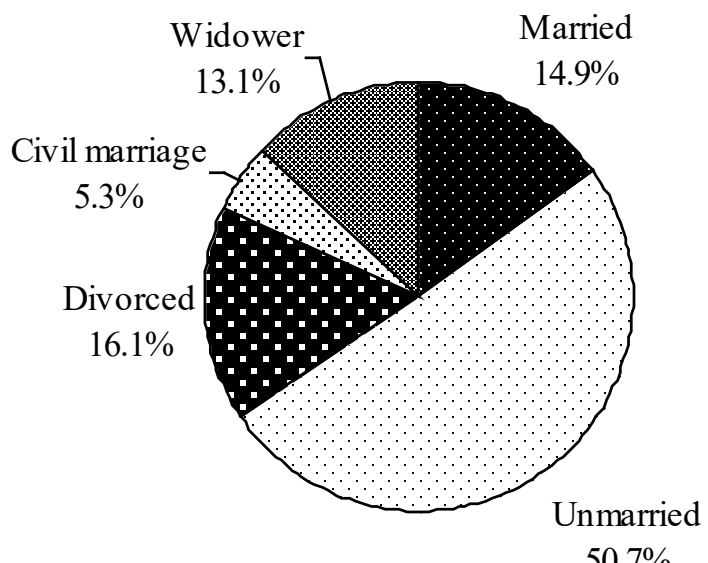

Fig. 5. The distribution by the marital status

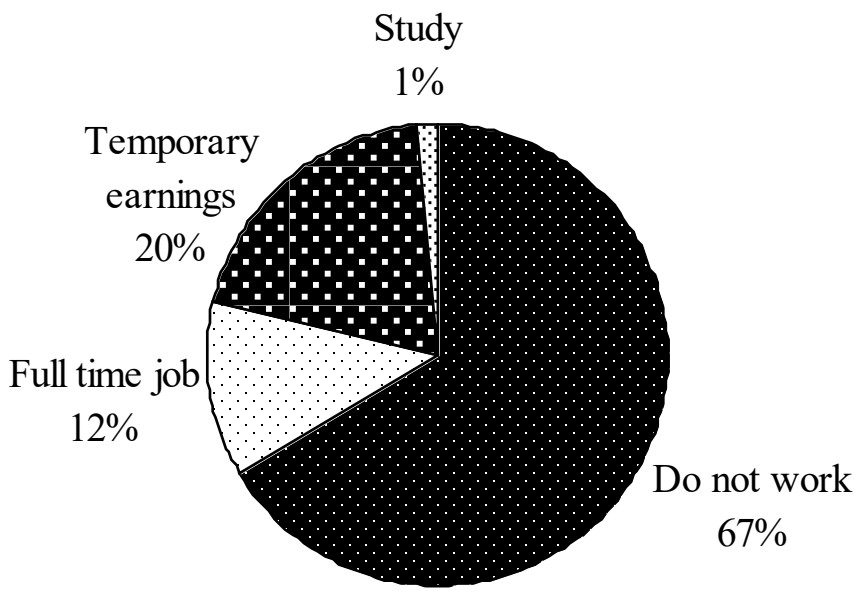

Fig. 6. The distribution of people under investigation by the features of work

(C) Zaviazkina Nataliia

DOI (article): https://doi.org/10.32626/2227-6246.2020-49.37-59 http://journals.uran.ua/index.php/2227-6246 


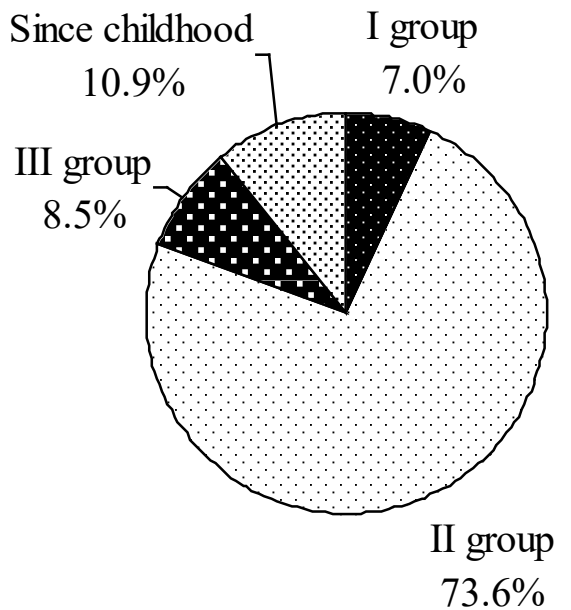

Fig. 7. Distribution of the unemployed persons according to the indicator of group of disability

The combination of these factors contributes to the formation of a higher level of "pre-criminal» behavior and readiness to the open illegal behavior, causes the rise in criminal tension in society and subsequently becomes the norm of behavior.

The intellectual component of the ability to understand and manage the meaning of one's actions is considered as a violation of the ability to be aware of the external and meaningful side of legally significant events, a breach of critical appraisal of the situation, and a prediction of consequences. The strong-willed component is revealed through to the violation of personal and motivational regulation of behavior, violation of adequate formation of the purpose and ability to regulation of behavior and control. According to the analysis of our data (Fig. 8-9) we can notice that indicators of understanding the purpose of examination, the actions and critical abilities are interconnected among themselves and reflect a picture of the general methodological approach when conducting examinations with the participation of psychologists.

(c) Zaviazkina Nataliia

DOI (article): https://doi.org/10.32626/2227-6246.2020-49.37-59 


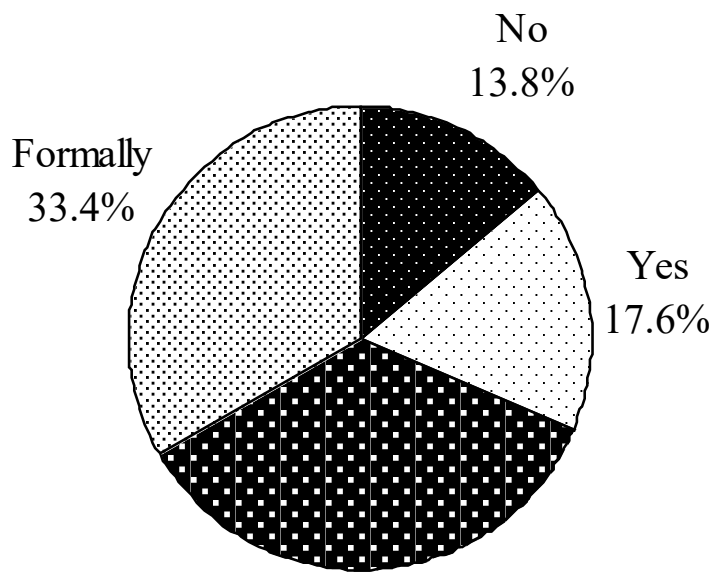

Incompletely

$35.2 \%$

Fig. 8. Understanding of the purpose of examination

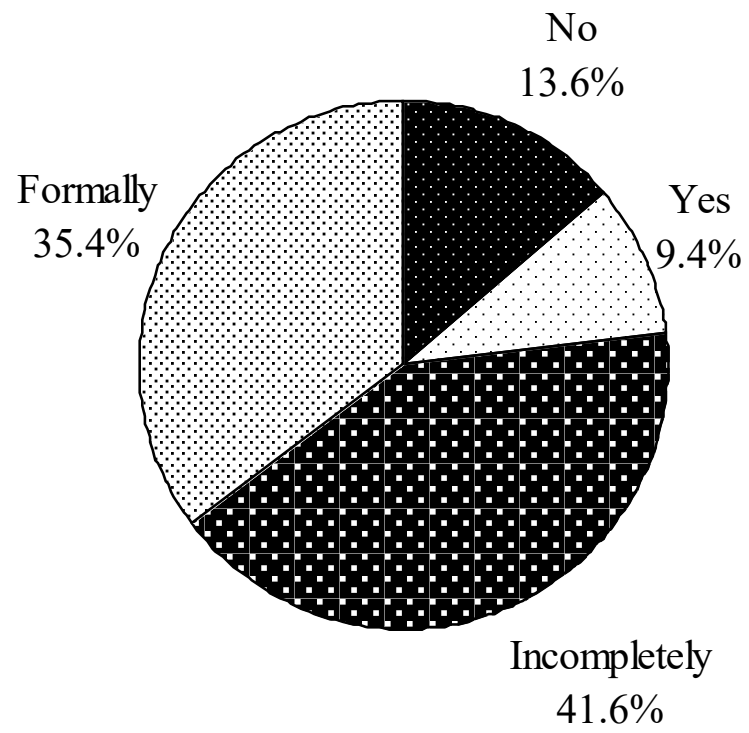

Fig. 9. Understanding of sense of personal actions (C) Zaviazkina Nataliia

DOI (article): https://doi.org/10.32626/2227-6246.2020-49.37-59 http://journals.uran.ua/index.php/2227-6246 
While analyzing the developed substantial characteristics of an intellectual component of legal (psychological) criterion it becomes obvious that they comprise of two types of characteristics: those belonging to the higher mental functions (criticality, prognosis), the second - belonging to the content of consciousness («legal meaning», «social meaning»). At the same time the strong-willed component of legal criterion coordinates with semantic and target levels of regulation of activity ("purposefulness of behavior», "personal-motivational regulation»).

Thus, the data obtained, underline that at the pronouncement of the expert opinion about limited ability of individuals to understand the value of their actions and to manage them, it is necessary to consider a number of indicators, beginning from psychopathological (the leading psychopathological syndrome with determination of depth of psychopathological manifestations), as well as social (working capacity, marital status, the system of communications and relationship of the subexpert persons with a microenvironment) and psychological criteria (direct or indirect subjective relation of the sub-expert persons (motivation) that will be considered in future works in details.

\section{Conclusions}

The mental condition of the person is defined by the forensic-psychiatric examination, or complex forensic psycho-psychiatric examination appointed after the establishment of the fact of commission of socially dangerous act by the person in the presence of the data raising doubts in his sanity. The mental disorders and certain conditions of mentality influencing an intellectual and strong-willed field of activity of the personality don't always automatically deprive him of the opportunity at the time of crime to realize the actual nature and public danger of the actions (inaction) or to manage them.

(C) Zaviazkina Nataliia

DOI (article): https://doi.org/10.32626/2227-6246.2020-49.37-59 
Undoubtedly, persons with mental disorders have a peculiar orientation in the external and internal reality. But, despite the fact that in inner world of people with mental anomalies certain events do not coincide with the standard representations, they have the so-called contextual framework of rather admissible and inadmissible behavior in society. Therefore, regulating rules of establishment of criminal liability, the legislation of a number of the countries provided the law where the responsible person, during commission of crime owing to a mental disorder could not realize fully the actual nature and public danger of the actions (inaction) or direct them, is the subject to criminal liability. This legal principle is referred to in the legal literature as «limited (reduced) conviction».

The thorough data of forensic psychology demonstrate that a person who has committed a socially dangerous act, the intellectual and volitional disorders, emotional disorders, lack of self-criticism, self-control, limited interests do not allow to apply adequate decisions to a specific situation, to act on a specific situation, in legal and moral standards. An important point in complex assessment of the factors defining the expert opinion is studying the criminal situation that allows estimating extent of updating and influence of the psychopathological frustration which is available in sub-expert person, his ability to full regulation of the behavior during the commission of illegal acts.

\section{Literature}

Антонян Ю. М., Бородин С. В. Преступность и психические аномалии. Москва : Наука, 1987. 208 с.

Балабанова Л. М. Судебная патопсихология (вопросы определения нормы и отклонений). Днепропетровск : Сталкер, 1998. 432 с.

Блейхер В. М., Крук И. В., Боков С. Н. Клиническая патопсихология: руководство для врачей и клинических психологов: учеб. пособие. Санкт-Петербург : МОДЭК, 2009. 623 с.

Вандыш-Бубко В. В., Сафуанов Ф. С. Ограниченная вменяемость: судебно-экспертологический анализ. Юридическая психология. 2009. № 2. C. 6-9. 
Гнетнев И. Г. Лица, страдающие психическими расстройствами, не исключающими вменяемости, как объект криминалистического исследования. Юристъ-Правоведъ. 2012. № 5. С. 21-23.

Гриневич Е. Г., Линский И. В. Катастрофы и невротические расстройства в Украине. Архів психіатрї. 2005. Т. 11. № 4. С. 7-13.

Зайцев О. В. Співвідношення осудності, неосудності та обмеженої осудності. Держава і право. 2003. Вип. 20. С. 395-399.

Иванников В. А. Психологические механизмы волевой регуляции: учеб. пособие для вузов. Санкт-Петербург : Питер, 2006. 208 с.

Ілейко В. Р., Первомайський В. Б. Обґрунтування експертних висновків в акті судово-психіатричної експертизи. Український медичний часопис. 2003. № 4. С. 105-108.

Карпец И. И. О понятиях вменяемости и невменяемости в проблеме борьбы с преступностью. Психические расстройства, не исключаюшие вленяелости (клинические и судебно-психиатрические аспекты ): Сборник научных трудов. Москва, 1984. С. 3-11.

Кудрявцев И. А. Комплексная судебная психолого-психиатрическая экспертиза: науч.-практ. руководство. Москва : Изд-во Моск. ун-та, 1999. 494 c.

Лапшина Е. Н. Саморегуляция лиц с пограничной психической патологией, совершивших правонарушение и признанных ограниченно вменяемыми. Сои. и клин. психиатрия. 2006. Вып. 4. С. 47-54.

Лунц Д. Р. Проблема невменяемости в теории и практике судебной психиатрии. Москва : Медицина, 1966. 236 с.

Марута Н. О., Мінько Н. О. Емоційні порушення при пограничних психічних розладах та алкогольній залежності (діагностика та принципи лікування). Харків, 2003. 20 с.

Медведєв В. С. Психологія злочинної діяльності: навч. посібник. Київ, 2012. 204 c.

Морозова М. В., Савина О. Ф. Проблема интеграции специалистов в экспертизе по уголовным делам: пределы компетенции психолога-эксперта при оценке вменяемости. Психология и право. 2011. № 2. C. $1-9$.

Назаренко Г. В. Невменяемость: уголовно-релевантные психические состояния. Санкт-Петербург : Изд-во «Юридический центр Пресс» . 2002. 207 c.

Первомайский В. Б. Понятие «общественная опасность душевнобольного» в судебной психиатрии. Государство и право. 1992. № 7. С. 59-67.

Приходько Т. М. Проблема зменшеної осудності у кримінальному праві. Одеса : Маяк, 1998. 56 с.

(c) Zaviazkina Nataliia

DOI (article): https://doi.org/10.32626/2227-6246.2020-49.37-59 
DOI: https://doi.org/10.32626/2227-6246.2020-49 2020. ВипУСК 49

Сафуанов Ф.С. Судебно-психологическая экспертиза в уголовном процессе. Москва : Смысл, 1998. 189 с.

Хамитов Р. Р. Сопряженность клинико-демографических показателей с характером деликтов психически больных, представляющих особую опасность. Рос. психиатр. журнал. 2003. № 3. С. 42-45.

Шостакович Б. В. Основы судебной психиатрии. Москва : ГУ ВШЭ, 2005. 218 c.

De Rosa, C., Luciano, M., Del Vecchio, V., Sampogna, G., Del Gaudio, L., Fizzotti, C., \& et al. (2013). Urban insecurity and fear of crime in people suffering from patients with mental disorders: preliminary results of a multicentric Italian study. Riv. Psichiatr, 48 (4), 321-327.

Vinkers, D. J., Beurs, de E., Barendregt, M., Rinne, Th., \& Hoek, H. W. (2011). The relationship between mental disorders and different types of crime. Crim. Behav. Ment. Health, 21 (5), 307-320.

\section{References}

Antonian, Yu. M., \& Borodin, S. V. (1987). Prestupnost i psikhicheskiie anomalii [Crime and mental anomalies]. Moskva : Nauka [in Russian].

Balabanova, L. M. (1998). Sudebnaia patopsikhologiia (voprosy opredeleniia normy $i$ otklonenii) [Forensic pathopsychology (rules and deviation issues)]. Dnepropetrovsk : Stalker [in Russian].

Bleikher, V. M., Kruk, I. V., \& Bokov, S. N. (2009). Klinicheskaia patopsikhologiia [Clinical pathopsychology]. Sankt-Peterburg : MODEK [in Russian].

Vandysh-Bubko, V. V., \& Safuanov, F. S. (2009). Ogranichennaia vmeniaiemost: sudebno-ekspertologicheskii analiz [Limited Sanity: Forensic Expert Analysis]. Yuridicheskaia psikhologiia - Law psychology, 2, 6-9 [in Russian].

Gnetnev, I. G. (2012). Litsa, stradaiushchiie psikhicheskimi rasstroistvami, ne iskliuchaiushchimi vmeniaiemosti, kak obiekt kriminalisticheskogo issledovaniia [Persons suffering from mental disorders that do not exclude imputability as a subject of forensic research]. Yurist-Pravoved - Lawyer-Legist, 5, 21-23 [in Russian].

Grinevich, E. G., \& Linskii, I. V. (2005). Katastrofy i nevroticheskiie rasstroistva $\mathrm{V}$ Ukraine [Accidents and neurotic frustration in Ukraine]. Arkhiv psykhiatrii - Archives of psychiatry, 4 (11), 7-13 [in Russian].

Zaitsev, O. V. (2003). Spivvidnoshennia osudnosti, neosudnosti ta obmezhenoi osudnosti [Ratio of sanity, insanity and limited sanity]. Derzhava i pravo - State and law, 20, 395-399 [in Ukrainian].

(C) Zaviazkina Nataliia

DOI (article): https://doi.org/10.32626/2227-6246.2020-49.37-59 
Ivannikov, V. A. (2006). Psikhologicheskiie mekhanizmy volevoi reguliatsii [Psychological mechanisms of will regulation]. Sankt-Peterburg [in Russian].

Ileiko, V. R., \& Pervomaiskii, V. B. (2003). Obgruntuvannia ekspertnykh vysnovkiv v akti sudovo-psykhiatrychnoi ekspertyzy [Justification of expert conclusions in the act of forensic-psychiatric examination]. Ukrainskyi medychnyi chasopys - Ukrainian Medical Journal, 4, 105-108 [in Ukrainian].

Karpets, I. I. (1984). O poniatiiakh vmeniaiemosti i nevmeniaiemosti v probleme borby s prestupnostiu [Concepts of sanity and insanity in the fight against crime]. Psikhicheskiie rasstroistva, ne iskliuchaiushchiie vmeniaiemosti (klinicheskiie i sudebno-psikhiatricheskiie aspekty ) - Mental disorders that do not exclude sanity (clinical and forensic psychiatric aspects ): Collection of research papers, (pp. 3-11). Moskva [in Russian].

Kudriavtsev, I. A. (1999). Kompleksnaia sudebnaia psikhologo-psikhiatricheskaia ekspertiza [Comprehensive forensic psycho-psychiatric examination]. Moskva : Izd-vo Mosk. un-ta [in Russian].

Lapshina, E. N. (2006). Samoreguliatsiia lits s pogranichnoi psikhicheskoi patologiiei, sovershivshikh pravonarusheniie i priznannykh ogranichenno vmeniaiemymi [Self-regulation of persons with a border mental pathology who have committed an offence and were recognized to be limited imputed]. Sotsialnaia i klinicheskaia psikhiatriia - Social and clinical psychiatry, 4, 47-54 [in Russian].

Lunts, D. R. (1966). Problema nevmeniaiemosti $v$ teorii i praktike sudebnoi psikhiatrii [The problem of insanity in the theory and practice of forensic psychiatry]. Moskva : Meditsina [in Russian].

Maruta, N. O., \& Minko, N. O. (2003). Emotsiini porushennia pry pohranychnykh psykhichnykh rozladakh ta alkoholnii zalezhnosti (diahnostyka ta pryntsypy likuvannia) [Emotional violations at boundary mental disorders and alcohol addiction (diagnostics and principles of treatment)]. Kharkiv [in Ukrainian].

Medvediev, V. S. (2012). Psykholohiia zlochynnoi diialnosti [Psychology of criminal activity]. Kyiv [in Ukrainian].

Morozova, M. V., \& Savina O. F. (2011). Problema integratsii spetsialistov v ekspertize po ugolovnym delam: predely kompetentsii psikhologaeksperta pri otsenke vmeniaiemosti [The problem of integration of specialists in expertise in criminal cases: limits of competence of a psychologist-expert in the assessment of imputability]. Psikhologiia i pravo - Psychology and law, 2, 1-9 [in Russian].

(c) Zaviazkina Nataliia

DOI (article): https://doi.org/10.32626/2227-6246.2020-49.37-59 
Nazarenko, G. V. (2002). Nevmeniaiemost: ugolovno-relevantnyie psikhicheskiie sostoianiia [Insanity: criminal and relevant mental states]. Sankt-Peterburg : Izd-vo "Yuridicheskii tsentr Press» [in Russian].

Pervomaiskii, V. B. (1992). Poniatiie «obshchestvennaia opasnost dushevnobolnogo" v sudebnoi psikhiatrii [The concept of public danger of the insane person in the forensic psychiatry]. Gosudarstvo i pravo State and law, 7, 59-67 [in Russian].

Prykhodko, T. M. (1998). Problema zmenshenoi osudnosti u kryminalnomu pravi [The problem of limited imputability in criminal law]. Odesa : Maiak [in Ukrainian].

Safuanov, F. S. (1998). Sudebno-psikhologicheskaia ekspertiza v ugolovnom protsesse [Forensic psychological examination in criminal proceedings]. Moskva : Smysl [in Russian].

Khamitov, R. R. (2003). Sopriazhennost kliniko-demograficheskikh pokazatelei s kharakterom deliktov psikhicheski bolnykh, predstavliaiushchikh osobuiu opasnost [The connection of clinical and demographic indicators with the nature of delicts of mental patients, which pose a special danger]. Rossiiskii psikhiatricheskii zhurnal Russian Journal of Psychiatry, 3, 42-45 [in Russian].

Shostakovich, B. V. (2005). Osnovy sudebnoi psikhiatrii [The basics of forensic psychiatry]. Moskva : GU VSHE [in Russian].

De Rosa, C., Luciano, M., Del Vecchio, V., Sampogna, G., Del Gaudio, L., Fizzotti, C., \& et al. (2013). Urban insecurity and fear of crime in people suffering from patients with mental disorders: preliminary results of a multicentric Italian study. Riv. Psichiatr, 48 (4), $321-327$.

Vinkers, D. J., Beurs, de E., Barendregt, M., Rinne, Th., \& Hoek, H. W. (2011). The relationship between mental disorders and different types of crime. Crim. Behav. Ment. Health, 21 (5), 307-320.

\section{Завязкіна Наталія. Особливості кримінальної поведінки осіб із психіч- ними розладами, які були визнані обмежено осудними}

\section{АНОТАЦІЯ}

У роботі наголошено на актуальності проблеми кримінальної відповідальності осіб із психічними розладами, що не виключає осудності. Це обумовлено, з одного боку, збільшенням серед осіб, які скоїли злочин, осіб із психічними відхиленнями за рахунок загального падіння рівня психічного здоров'я населення, з іншого боку, відсутністю чіткого законодавчого вирішення питання про кримінально-правове значення психіч(C) Zaviazkina Nataliia

DOI (article): https://doi.org/10.32626/2227-6246.2020-49.37-59 http://journals.uran.ua/index.php/2227-6246 
них аномалій при індивідуалізації покарання. Наголошено на необхідності аналізу впливу на здійснення противоправного діяння відповідного комплексу даних.

Мета статmi - розкрити особливості даних щодо кримінальної поведінки осіб із психічними розладами, які були визнані обмежено осудними.

Для досягнення завдань було використано такі методи: теоретичний аналіз наукової літератури, психодіагностичні та статистичні меmodu.

у дослідженні було проаналізовано 103 випадки осіб, які проходили комплексну психолого-психіатричну експертизу та були визнані такими, які не могли повною мірою усвідомлювати характер і значення власних дій у період правопорушення, тобто обмежено осудними.

Результати дослідження показали, що психічний стан особи визначається судово-психіатричною експертизою або комплексною судово-психолого-психіатричною експертизою, яка призначається після встановлення факту вчинення суспільно небезпечного діяння цією особою за наявності даних, що викликають сумнів щодо їі осудності. 3’ясовано, що психічні розлади і певні стани психіки, що впливають на інтелектуально-вольову среру діяльності особистості, не завжди автоматично позбавляють ії можливості у момент скоєння злочину усвідомлювати фактичний характер і громадську небезпеку свої дій (бездіяльності) або керувати ними.

Висновок. Доведено, що особа, яка скоїла суспільно небезпечне діяння, потребує вивчення порушень в інтелектуальній і емоційно-вольовій сфрерах, критичності, самоконтролю, а також вивчення кримінальної ситуації, що дає змогу оцінити ступінь актуалізації та впливу психопатологічного розладу, наявного у підекспертного, на його здатність до повноцінної регуляції своєї поведінки у період здійснення протиправних diŭ.

Ключові слова: кримінальна поведінка, обмежена осудність, індивідуалізація покарання, психічні розлади, інтелектуальна діяльність, вольові процеси, емочійна сфера.

Завязкина Наталия. Особенности криминального поведения лиц с психическими расстройствами, которые были признаны ограниченно вменяемыми

(C) Zaviazkina Nataliia

DOI (article): https://doi.org/10.32626/2227-6246.2020-49.37-59 


\section{АННОтАЦИЯ}

В работе отмечена актуальность проблемы уголовной ответственности лиц с психическими расстройствами, не исключающей вменяемости. Это обусловлено, с одной стороны, увеличением среди лии, совершивших преступление, лиц с психическими отклонениями, за счет общего падения уровня психического здоровья населения, с другой стороны, отсутствием четкого законодательного решения вопроса об уголовно-правовом значении психических аномалий при индивидуализации наказания. Отмечена необходимость анализа влияния на осуществление противоправного деяния соответствующего комплекса данных.

Цель статьи заключается в раскрытии особенностей данных в отношении криминального поведения лиц с психическими расстройствами, которые были признаны ограниченно вменяемыми.

Для достижения задач были использованы следующие методы: теоретический анализ научной литературы, психодиагностические и статистические методы.

В исследовании были проанализированы 103 случая лии, проходивших комплексную психолого-психиатрическую экспертизу и признанных таковыми, которые не могли в полной мере осознавать характер и значение своих действий в период правонарушения, то есть, ограниченно вменяемыми.

Результаты исследования показали, что психическое состояние лица определяется судебно-психиатрической экспертизой или комплексной судебно-психолого-психиатрической экспертизой, назначаемой после установления факта совершения общественно опасного деяния при наличии данных, вызывающих сомнение в вменяемости личности. Выяснено, что психические расстройства и определенные состояния психики, влияющие на интеллектуально-волевую сферу личности, не всегда автоматически лишают ее возможности в момент совершения преступления осознавать фактический характер и общественную опасность своих действий (бездействия) либо руководить ими.

Вывод. Доказано, что лицо, совершившее общественно опасное деяние, требует изучения нарушений в интеллектуальной и эмоционально-волевой срерах, критичности, самоконтроля, а также изучения криминальной ситуации, что позволяет оценить степень актуализации и влияния психопатологического расстройства, отмеченного у подэкс(C) Zaviazkina Nataliia

DOI (article): https://doi.org/10.32626/2227-6246.2020-49.37-59 
ISSN 2227-6246 (Print)

DOI: https://doi.org/10.32626/2227-6246.2020-49

2020. ВИПУСК 49

пертного, на его способность к полноценной регуляции своего поведения в период совершения противоправных действий.

Ключевые слова: криминальное поведение, ограниченная вменяемость, индивидуализация наказания, психические расстройства, интеллектуальная деятельность, волевые процессы, эмоциональная сфера.

Original manuscript received April 09, 2020

Revised manuscript accepted May 14, 2020

(c) Zaviazkina Nataliia

DOI (article): https://doi.org/10.32626/2227-6246.2020-49.37-59 